\title{
Assessment of Environmental Sensitivity to Desertification, Soil Quality and Sustainability in An Area of The North Nile Delta, Egypt
}

\author{
Heba Elbasiouny \\ Department of Environmental and Biological Science, Faculty of Home Economy, \\ Al-Azhar University, Egypt
}

\begin{abstract}
$\mathbf{T}$ HERE IS a growing concern about interconnected environmental issues such as environmental changing, degradation, anddesertification.Therefore, the integration of assessment studies of environmental sensitivity, soil quality and sustainability is very important in planning and decision making in degraded and vulnerable areas to degradation,especially when associated to spatial distribution of such issues. Therefore, this study aims to: assess the environmental sensitivity (ES) to desertification, as well as soil quality (SQ) and sustainability (SS) in an area of North Nile Delta as a vital and fertile area that subjected to many challenges; as well, to utilize the GIS tools and capabilities to interpolate ES, SQ, and SS. MEDALUS scheme is used to assess ES. In this scheme four factors (i.e. soil(S), climate (C), vegetation $(\mathrm{V})$, and management $(\mathrm{M})$ ) are considered. On the other hand, nine soil properties were considered to evaluate the SQ andSS. The results of this study revealed that all study area is classified as critical or fragile environmentally sensitive areas (ESAs). The most critical part is the southern of the study area.As well, the results demonstrated lowering in SQ and extending in unsustainable parts especially in the degraded, and barren parts in the north and most of the west area. It is also observed that although all southern part in the study area is sensitive to degradation, there was a part is considered as high quality and sustainable. Such assessment studies provide a framefor systematic and subjectiveevaluating of the potential subjecting of these areasto significant environmental impacts which should considered in the strategic planning in this area.
\end{abstract}

Key words: Environmental sensitivity, Soil quality, Soil sustainability, Nile Delta, Egypt.

\section{Introduction}

Increasing human pressure in ecosystems has led to a significant extension of degraded lands and a considerable loss of SQ over the last decades (Tombolini et al., 2016). Furthermore, due to an increased human population over the world, the need for food, clean water and biofuels is rising. This demand is expected to rise to 50 and $30 \%$, respectively through 2030 (Jónsson et al., 2016). Soil is one of the highest effective environmental factors and is a main source for providing vital plant nutrients, water reserve, and a medium for plant growing (Ghaemi et al., 2014). Hence, soil degradation is a serious threat to fulfill the expected demand of food and clean water, thus protecting and sustainable managing of soil resources become even more important (Jónsson et al. 2016)

When assessing the risk of soil degradation, the concept of ES aroused more than 30 years ago and has been latterly stimulated to increase awareness regarding desertification and soil degradation and their consequences (Contador et al., 2009). Zou and Yoshino (2017) reported that ES is relevant to the damage risk of the natural environment or a specific ecosystem. They also cited from (IPCC,2014) that vulner ability is the extent of which a system is susceptible to adversarial effects by a specific hazard or stressor. Assessing ES to desertification, as a global phenomenon affects 
about one billion people in about 100 countries, is very important to identify suspected areas to desertification (Saleh et al., 2018). This could be considered as a spatially delineated area where some main aspects related to its sustainability are unbalanced and not sustainable in a specific environment (Contador et al., 2009).

In addition, there is a necessity for monitoring and enhancing SQ, especially in degraded soils. As well, the successful management and enhancing soil quality are integrative indicators of sustainable agriculture, maintaining or improvingthe environmental quality and protecting natural resources (Seker et al., 2017). SQ is a multifaceted conception reflecting the ability of soil to sustain agricultural production and natural vegetation (Tombolini et al., 2016). It is defined as: "the capacity of specific soil to sustain biological productivity and reserve the environmental quality and health of plants and animals in the boundaries of the ecosystem" (Seker et al., 2017 and Elbasiouny et al., 2017a cited from Doran and Parkin, 1994,Karlen et al., 1997).

The 2030 Agenda for Sustainable Development "The United Nations' Transforming our World" lists 17 Goal of Sustainable Development to motivate actions in critical areas for humanity and Earth planet until 2030. Soil sustainable management has direct relation to at least $50 \%$ of them and may also have indirect relevance for others. Therefore, assessing sustainability is an iterative, lasting, cooperating processand a vital tool for supporting the shift tosustainability and helping decision-makers to take or not take the actions toward it. Therefore, indicators and assessing tools are essential to reach the divers goals relating to sustainable development. Yet, practicable strategies to accomplishthese aims in harmony, especially regarding protecting and managing the ecosystems to support human well-being objectives, are not specified and raise important and critical research questions (Jónsson et al. 2016 and Wood et al., 2018). In the inclusive goal of achieving sustainability, the analysis of sensitivity should be an aim at the early identification stage of inherent risks affecting environmental resource protection/conservation. The ES analysis enables extra insight into the reference line environment to pure technical factoring of features. It is also considered a framework for systematically defining the potential for major impacts (Campo, 2017).
Therefore, the integration between assessing the environmental sensitivity, soil quality and sustainability is required for good management practices.

Using GIS tools, through operating integrated indicators, are a very interesting method to assess the complex environments that suffering from diffuse human induced processes (García-Ayllón, 2018). Such tools are used also to determine the spatial dynamics detected recently at both the regional and global and regional scales that require a continuous monitoring for identifying the most relating contributing factors (Tombolini et al., 2016).

The Nile Delta is one of the oldest intensely cultivated lands on the Earth. It is also very heavily populated (up to1600 individual $/ \mathrm{km}^{2}$ ) (Zeydan, 2005). Although Nile Delta is one of the most vital areas in the world, it is subjected to many challenges and environmental stresses, such as increasing population growth, unplanned urbanization, land subsidence, excessive erosion rates in coastal area, seawater intrusion, soil salinization, extensiveland use, degradation, lack of appropriate institutional management systems, pollution and climate change impacts (Elbasiouny et al., 2014 and Elbehiry et al., 2018). The studies ofES, SQ, and SS are very rare in this significant area. Subsequently, there is an essential need for observation and monitoring studies such as spatial distribution to be initial steps for minimizing any environmental risks there (Elbehiry et al., 2017).

Therefore, this study aims to: 1) assess the environmental sensitivity in Kafr El-Sheikh Governorate in the North Nile Delta Egypt; 2) evaluate soil quality and soil sustainability in this vital area of Egypt to establish data base for decision making, planning and good management practicing in this valuable area in Egypt; and 3) interpolate the sampled data for spatial distributed mapping of ES, SQ, and SS for future environmental monitoring purposes.

\section{Material and methods}

The study area and sampling sites

The study area is located on the south of Mediterranean Sea in North Nile Delta Egypt (Kafr Elsheikh governorate, Fig. (1)between the two branches of the Nile river (i.e. Rosetta and Damietta). Other boundaries of the study area are Gharbia, Dakahlia, and Elbehira Governorates in the south, east, and west respectively.Borullus

Egypt. J. Soil. Sci. 58, No. 4 (2018) 
Lake (UNESCO protected area) is located in this area (Fig. 1). The mean maximum and minimum temperature of this area is $28.9^{\circ} \mathrm{C}$ and $11.1^{\circ} \mathrm{C}$ respectively, while the annual mean precipitation is $138 \mathrm{~mm}$, and always falls in winter. Most of this area is intensively old cultivated (at least twice per year). Major crops in the studied area are rice (Oryza sativa), maize (Zea mays), wheat (Triticum sativum), clover (Trifolium), cotton (Gossypium barbadense), and sugar beet (Beta vulgaris). As well, the study area has new cultivated area in the North, this cultivated area is called graduation (Kheregeen) lands, which were very degraded (mostly salt affected soils) and reclaimed by agriculture faculties graduations. On the other hand, most of the coastal belt is barren and very degraded soils. The irrigation system is primarily surface (by Nile water or mixed water (i.e. drainage with Nile water)), while the drainage system is surface in some places and subsurface in the others. Mostly the water table level is about $1 \mathrm{~m}$ south the lake and $0.75 \mathrm{~m}$ toward the coast. Major landscape in the study area include cropping and urban systems, Borullus Lake, coastal plain, urban and industrial commercial centers and sand dunes in the coastal part of the study area (Fig. 2).

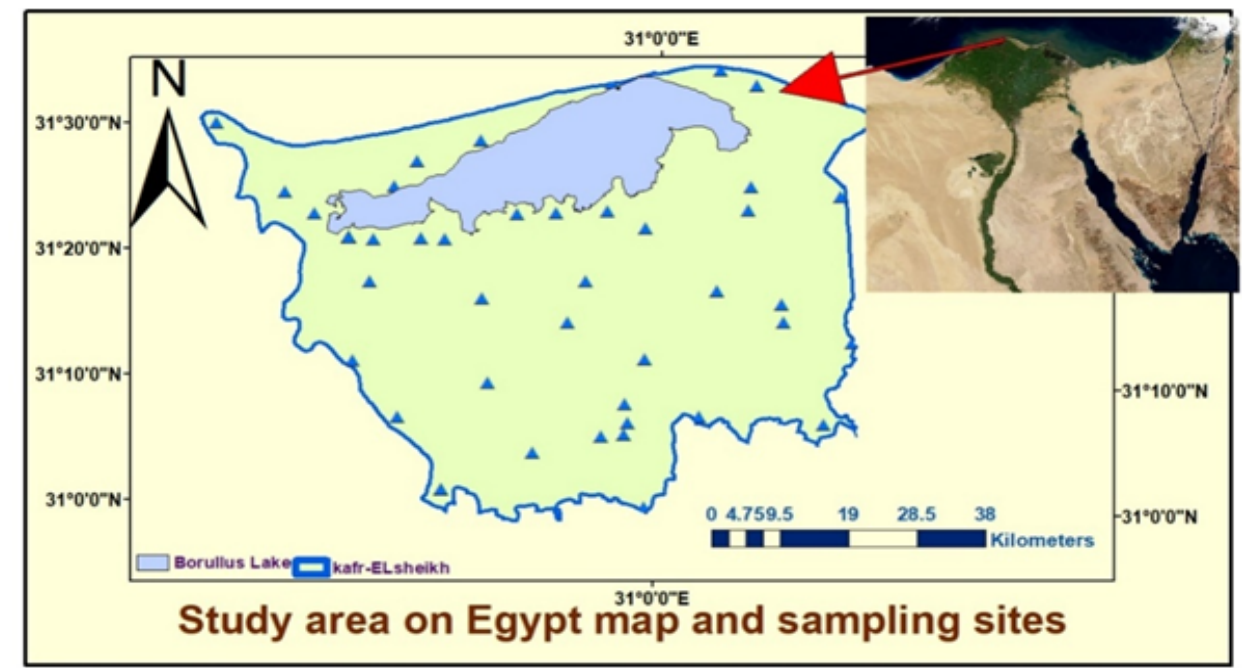

Fig. 1. Study area on Egypt map and sampling sites

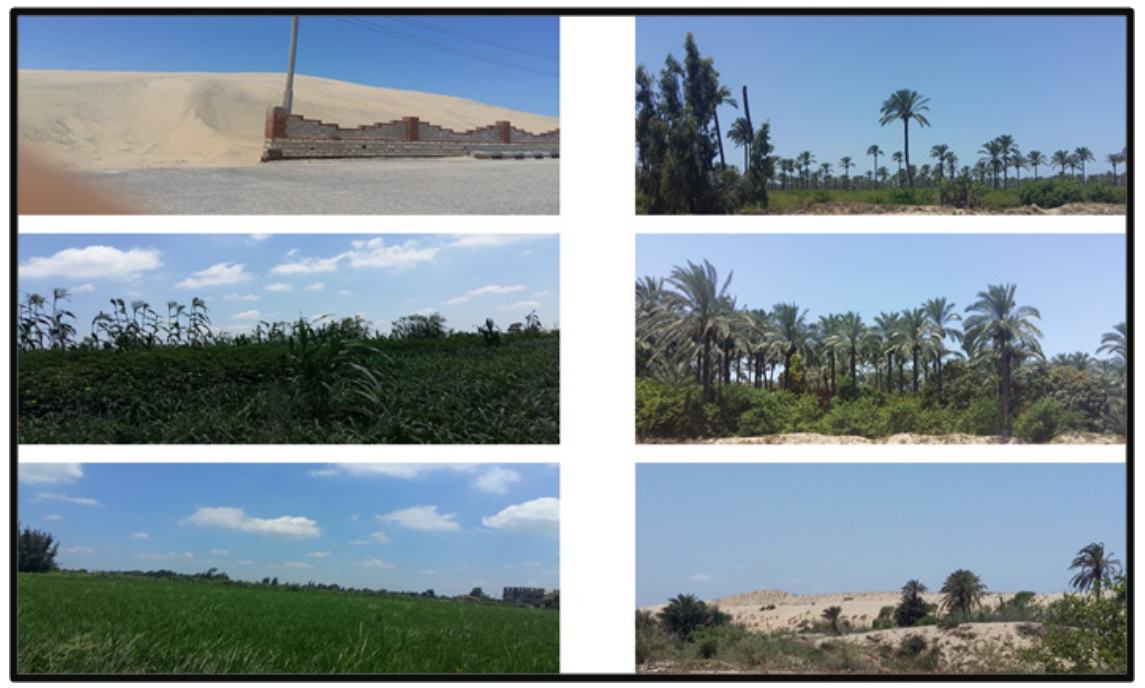

Fig. 2. Some Landscape views in the study area (palm trees, crops and sanddunes)

(The photos were taken by the author) 


\section{Sampling}

Soil samples (47 surface samples) were collected from different soil typesin the study area at $30 \mathrm{~cm}$ depth for size distribution analysis. Geographical locations of these profiles were acquired using GPS and coordinated in (Fig. 1).

\section{Data analysis}

The methodology for ESAs definition

The (ESA) scheme (i.e., MEDALUS) to identify and prioritize the agricultural areas that require to be protected, can be more largely applied for the assessing of land vulnerability degradation and desertification risk regionally and at country scale. This scheme is included 14 variables refer to four thematic fields (i.e. soil (S), climate (C), vegetation (V), and land management (M)) adopted from official and published data sources. A GIS was used to operationally manage the previous data in layers and to combined them into partial indicators to quantify the contribution of each thematic field to the complex index (Tombolini et al., 2016).

In the MEDALUS system, the four main concerned factors of $\mathrm{S}, \mathrm{C}, \mathrm{V}$ and $\mathrm{M}$ are joint in a synthetic way for producing ESA Index (ESAI). Data alone, nevertheless, is unusable without suitable tools for their effectual exploitation. In this context, sophisticated techniques must be utilized to acquire and manage these large amounts of spatialdata to solve the crucial and complicated problems of our day (Ferrara, 2004). The first three quality indices provide a framework of the environmental conditions, whereas, the last one refers to an assessment of the stress caused athropogenically. All the data describing the four quality indices are presented in a GIS and overlapped according to the developed algorithm and subsequently ESAs maps be compiled. The methodology is relied on the classification of each quality index acquired as the geometric average of the accessible environmental and anthropogenic parameter.

Data collection: A sensitivity index is not a directly measured parameter as it exhibits a potential susceptibility of an area to a specific phenomenon. However, a verification of the resulting classification is carried out by field visits, where overallconditions of land degradation is visually assessed (Izzo et al., 2013). The next data of the physical environment and land management are required for the definition of ESAs to land degradation: (a) soil; (b) vegetation;(c) climate; and (d) land management characteristics.
Soil quality (SQ): Soil is an essential factor in evaluating the ES of an ecosystem, especially in the semi-arid, arid, and dry sub-humid areas. Soil parameters correlated to degradation phenomena affect two major parameters: 1) water storage and retention capacity and 2) erosion resistance (Ali \& El Baroudy, 2008 and El- Baroudy, 2013). The complete evaluation of SQ with respect to these properties can be performed by using soil parameters given in regular soil survey reports, or lab analysis. Soil parameters and relative quantified scores are demonstrated in Table 1. Soil quality index (SQI) is then computed as the result of the attributes mentioned in Table 1 as in Eq. (1) using the properties and weights in Table 1 (Kosmas et al., 1999).

$\mathrm{SQI}=($ texture $\mathrm{x}$ parent material $\mathrm{x}$ rock fragment $\mathrm{x}$ depth $\mathrm{x}$ slope $\mathrm{x}$ drainage $)^{1 / 6}$

(Eq. 1)

The soil quality is then described based on the index score in Fig. 3.

Climate quality (CQ): The unequal annual and interannual distributing of rainfall, the sever events and the out of rainy and vegetative seasons in the arid and semi-arid zones of the Mediterranean are the main climatic features that contribute to the landdegradation.Global climate change is likely to expand the current geography of the vulnerable areas in this region. Any loss of these marginal lands greatly reduces the potential for biomass production (Kosmas et al., 1999). The climate attributes in Table 1 are involved in the assessment of CQ (Kosmas et al., 1999 and Ferrara, 2004). Climate quality index (SQI) is then computed as in Eq. 2 using the properties and weights in Table 1 (Kosmas et al., 1999).

$\mathrm{CQI}=(\text { rainfall } * \text { aridity*aspect })^{1 / 3}$

Climate layers and relative quantified scores are reported in Table 1. The climate quality is then defined based on the index score in Fig. 3.

Vegetation quality (VQ): Vegetation plays a significant role in alleviating the degradation effects. The VQ was calculated considering the criteria in Table 1 . The vegetation quality index (VQI) is computed using Eq.3. Then the VQI is categorized into three classes describing the quality of vegetation with respect to desertification (Fig. 3).

$\mathrm{VQI}=$ (fire risk $^{*}$ erosion protection*drought resistance* ${ }^{*}$ vegetation cover $)^{1 / 4}$

(Eq. 3) 
TABLE 1. Soil, climate, vegetation, and management parameters and their scores

\begin{tabular}{|c|c|c|c|}
\hline \multicolumn{4}{|c|}{ Soil } \\
\hline Description & & Classes & Scores \\
\hline \multirow{2}{*}{ Parent material } & Shale, basic, ultra-basic, & $\begin{array}{l}\text { schist, conglomerates, unconsolidated } \\
\text { marl (with natural vegetation), clays }\end{array}$ & 1.0 \\
\hline & \multicolumn{2}{|c|}{$\begin{array}{l}\text { Limestone, marble, ignibrite, gneiss, granite, rhyolite, siltstone, } \\
\text { sandstone, Marl, dolomite, Pyroclastics. }\end{array}$} & $\begin{array}{l}1.7 \\
2.0\end{array}$ \\
\hline \multirow{4}{*}{ Soil texture } & $\mathrm{L}, \mathrm{CL}, \mathrm{SCL}, \mathrm{SL}, \mathrm{LS}$ & & 10 \\
\hline & SC, SiCL, SiL & & 1.2 \\
\hline & $\mathrm{Si}, \mathrm{SiC}, \mathrm{C}$ & & 1.6 \\
\hline & $\mathrm{S}$ & & 2.0 \\
\hline \multirow{3}{*}{$\begin{array}{l}\text { Rock fragments } \\
\text { cover }(\%)\end{array}$} & more than 60 & & 1.0 \\
\hline & 20 to 60 & & 1.3 \\
\hline & less than 20 & & 2.0 \\
\hline \multirow{4}{*}{ Soil depth $(\mathrm{cm})$} & deep (deeper than $75 \mathrm{~cm}$ ) & & 1.0 \\
\hline & moderate $(75$ to $30 \mathrm{~cm})$ & & 2.0 \\
\hline & shallow $(15$ to $30 \mathrm{~cm})$ & & 3.0 \\
\hline & very shallow (less than $15 \mathrm{~cm}$ ) & & 4.0 \\
\hline \multirow{3}{*}{ Drainage } & well drained & & 1.0 \\
\hline & imperfectly drained & & 1.2 \\
\hline & poor drained & & 2.0 \\
\hline \multirow{4}{*}{ Slope (\%) } & higher than 6 & & 1.0 \\
\hline & 6 to 18 & & 1.2 \\
\hline & 18 to 35 & & 1.5 \\
\hline & less than 35 & & 2.0 \\
\hline \multicolumn{4}{|c|}{ Climate } \\
\hline \multirow{5}{*}{$\begin{array}{l}\text { Rainfall }(\mathrm{mm} / \\
\text { year })\end{array}$} & higher than 650 & & 1.0 \\
\hline & 280 to 650 & & 2.0 \\
\hline & less than 280 & & 4.0 \\
\hline & higher than 50 & & 1.0 \\
\hline & 50 to 75 & & 1.1 \\
\hline Aridity index: & 75 to 100 & & 1.2 \\
\hline \multirow[t]{3}{*}{ Bagnouls\&Gaussen } & 100 to 125 & & 1.4 \\
\hline & 125 to 150 & & 1.8 \\
\hline & less than 150 & & 2.0 \\
\hline \multirow{2}{*}{ Slope aspect } & North, NE, NW, plain & & 1.0 \\
\hline & South, SE, SW & & 2.0 \\
\hline \multicolumn{4}{|c|}{ Vegetation } \\
\hline \multicolumn{4}{|c|}{ Fire risk } \\
\hline $\mathrm{L}$ & $\begin{array}{l}\text { Bare lands, agriculture crops }( \\
\text { sunflower, tobacco) }\end{array}$ & erennial), agriculture crops (annual: maize, & Less than 1.13 \\
\hline M & $\begin{array}{l}\text { Agriculture crops (annual: cer } \\
\text { Mediterranean, mixed, macchi }\end{array}$ & $\begin{array}{l}\text { ls, grasslands), decidous oak, Mixed } \\
\text { forests (evergreen) }\end{array}$ & 1.13 to 1.45 \\
\hline $\mathrm{H}$ & Mediterranean macchia & & Higherthan 1.46 \\
\hline VH & Forests (pine) & & \\
\hline \multicolumn{4}{|c|}{ Erosion Protection } \\
\hline VH & Mixed Mediterranean, macchi & forests (evergreen) & 1.00 \\
\hline \multirow{2}{*}{$\mathrm{H}$} & Mediterranean macchia, forest & (pine) & \multirow{2}{*}{1.30} \\
\hline & Grasslands (permanent), crop & vergreen perennial) & \\
\hline M & Forests (deciduous) & & 1.60 \\
\hline
\end{tabular}


TABLE 1. Continued.

\begin{tabular}{|c|c|c|}
\hline $\mathrm{L}$ & Agriculture crops (dseciduous perennial: almond, orchards) & 1.80 \\
\hline VL & Agriculture crops (annual:cereals) grassland (annual), vines & 2.00 \\
\hline \multicolumn{3}{|c|}{ Drought Resistance } \\
\hline \multirow{2}{*}{$\mathrm{VH}$} & Mixed Mediterranean macchia/ forest (evergreen) & \multirow{2}{*}{1.00} \\
\hline & Mediterranean macchia & \\
\hline $\mathrm{H}$ & Conifers, olives, deciduous & 1.20 \\
\hline $\mathrm{M}$ & Agriculture crops (perennial: vines, ochrand, almonds) & 1.40 \\
\hline $\mathrm{L}$ & Grasslnds (perennial) & 1.70 \\
\hline VL & Agriculture crops (annual), grasslands (annual) & 2.00 \\
\hline \multicolumn{3}{|c|}{ Plant Coverpercentage } \\
\hline $\mathrm{H}$ & higher than $40 \%$ & 1.00 \\
\hline $\mathrm{L}$ & 10 to $40 \%$ & 1.80 \\
\hline VL & $<$ less than $10 \%$ & 2.00 \\
\hline \multicolumn{3}{|c|}{ Management } \\
\hline \multicolumn{3}{|c|}{ Natural Areas } \\
\hline $\mathrm{L}$ & $\mathrm{A} / \mathrm{S}=0$ & 1.0 \\
\hline $\mathrm{M}$ & $\mathrm{A} / \mathrm{S}<1$ & 1.2 \\
\hline $\mathrm{H}$ & $\mathrm{A} / \mathrm{S}=1$ or greater & 2.0 \\
\hline \multicolumn{3}{|c|}{ Land use intensity for pastures } \\
\hline $\mathrm{L}$ & $\mathrm{ASR}<\mathrm{SSR}$ & 1.0 \\
\hline $\mathrm{M}$ & $\mathrm{ASR}=\mathrm{SSR}$ to $1.5 * \mathrm{SSR}$ & 1.5 \\
\hline $\mathrm{H}$ & $\mathrm{ASR}>1.5 * \mathrm{SSR}$ & 2.0 \\
\hline \multicolumn{3}{|c|}{ Land use intensity for croplands } \\
\hline $\mathrm{L}$ & Low land use intensity (LLUI) & 1.0 \\
\hline $\mathrm{M}$ & Medium land use intensity (MLUI) & 1.5 \\
\hline $\mathrm{H}$ & High land use intensity (HLUI) & 2.0 \\
\hline \multicolumn{3}{|c|}{ Mining Areas } \\
\hline $\mathrm{L}$ & Adequate & 1.0 \\
\hline $\mathrm{M}$ & Moderate & 1.5 \\
\hline $\mathrm{H}$ & Low & 2.0 \\
\hline \multicolumn{3}{|c|}{ Recreation Areas } \\
\hline $\mathrm{L}$ & Less than 1 & 1.0 \\
\hline $\mathrm{M}$ & 1 to 2.5 & 1.5 \\
\hline $\mathrm{H}$ & higher than 2.5 & 2.0 \\
\hline \multicolumn{3}{|c|}{ Policy } \\
\hline $\mathrm{H}$ & Complete protection;more than $75 \%$ ofthe area is under protection & 1.0 \\
\hline $\mathrm{M}$ & Partial: 25 to $75 \%$ ofthe area is under protection & 1.5 \\
\hline $\mathrm{L}$ & Incomplete: less than $25 \%$ ofthe area under protection & 2.0 \\
\hline
\end{tabular}

L: low; M: moderate; H: high; VL: very low; VH: very high; SSR: sustainable stocking rate; ASR: actual stocking rate. Source:(Kosmas et al., 1999, Ferrara, 2004, Canora et al., 2015). 


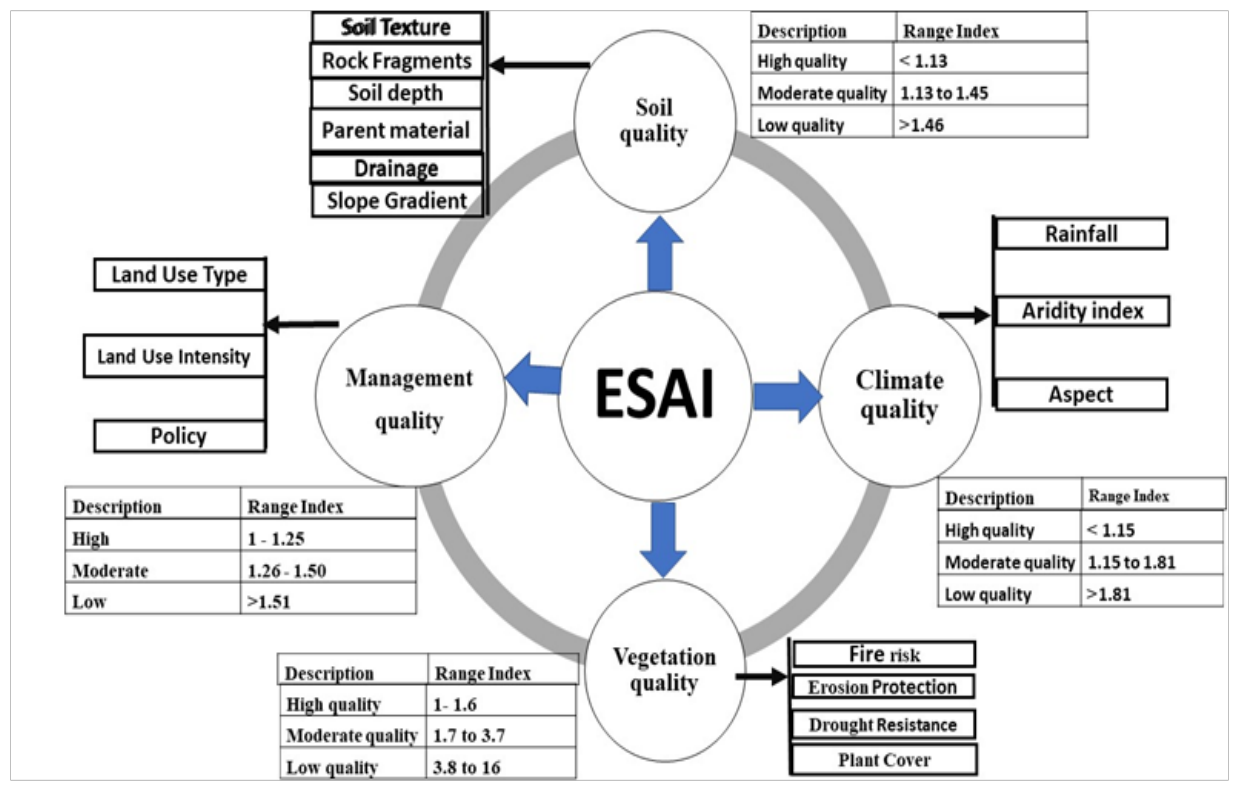

Fig. 3. Indices and related parameters operated for definition and mapping the ESAs to desertification

Source: Derived from Kosmas et al. (1999).

Management quality: Kosmas et al. (1999) and Ferrara (2004) reported that, considering the main land uses for assessing the degree of management quality of human induced pressure, the land is firstly categorized in the five categories described in Table 1. After defining the type of land use in a certain piece of land, the intensity of land use and the enforcement of policy on environmental protection (Table 1) is assessed. The management quality index (MQI) is computed as the product of management characteristics (Table 1) related to sensitivity using Eq. (4).

$\mathrm{MQI}=(\text { land use intensity* policy enforcement })^{1 / 2}$

The MQI is categorized into three classes describing the quality of management regarding desertification (Fig. 3).The four derived indices are then multiplied for the assessment of the ESAs index (ESAI) as following (Eq. 5):

$$
\mathrm{ESAI}=\left(\mathrm{SQI} * \mathrm{CQI}{ }^{*} \mathrm{VQI}{ }^{*} \mathrm{MQI}\right)^{1 / 4}
$$

\section{Soil quality (SQ) and sustainability (SS)}

Soil quality (SQ) and sustainability (SS) were assessed based on the same way of (Ghaemi et al., 2014). Nine soil indicators were considered as data set for assessing the quality and sustainability of the studied soil (Table 2). A total of 20 soil samples representing all soils, landscapes and ecosystems were selected to standard laboratory procedures (not all samples that included in ESAI calculation were considered in assessing soil quality and sustainability because of the analysis cost) on air dried soil, gently ground, and sieved through $2 \mathrm{~mm}$ sieve. The $\mathrm{pH}$ was measured at 1: 2.5 (W/V) (soil: water) suspension according to (Page et al., 1982). The electrical conductivity (EC) was measured on soil paste extract according to (United States Salinity Laboratory Staff, 1954). Soluble $\mathrm{Na}, \mathrm{Ca}$, and $\mathrm{Mg}$ were measured in soil paste to calculate the Sodium Adsorption Ratio (SAR).Bulk density (BD) was measuredconsidering soil organic matter (SOM) concentration (\%) according to Xu et al. (2015) as cited from Adams (1973) as presented in Eq. 6. Particle size distribution was measured and calculated based on the pipette method. The SOC was measured by wet combustion method, where SOM is determined by by $\mathrm{K}_{2} \mathrm{Cr}_{2} \mathrm{O}_{7}-\mathrm{H}_{2} \mathrm{SO}_{4}$ (i.e., titrimetric determination (Walkley and Black method)); or as called also: oxidation method; (Nelson and Sommers, 1996). Then, SOC is calculated by $\mathrm{Mgha}^{-1}$ by the following equation (Eq. 7) according to Adams (1973):

$$
\mathrm{BD}=100 /\left\{\left(\mathrm{OM} \% / \mathrm{K}_{1}\right)+\left(100-\mathrm{OM} \% / \mathrm{K}_{2}\right)\right\}
$$

where $\mathrm{BD}$, soil bulk density $\left(\mathrm{g} \mathrm{cm}^{-3}\right)$; OM, organic matter (\%); $\mathrm{K}_{1}$, bulk density of SOM $(0.244 \mathrm{~g}$ $\left.\mathrm{cm}^{3}\right) ; \mathrm{K}_{2}$, bulk density of mineral matter $(1.64 \mathrm{~g}$ $\mathrm{cm}^{-3}$ ).

SOC $\left(\mathrm{Mg} \mathrm{ha}^{-1}\right)=10^{4} \times \mathrm{Cs} \times \mathrm{h} \times \mathrm{BD} / 100 \quad$ (Eq.7) (Elbasiouny et al., 2014). 
where, Cs: the soil carbon concentration $\%$; h: the depth of soil layer (m); and BD: the bulk density $\left(\mathrm{g} \mathrm{cm}^{-3}\right)$.

Relative field capacity (RFC), available water holding capacity (AWHC) and air capacity (AC) were derived from published data based on the same texture (El-Nesr, 2006 cited from Keller and Karmeli, 1975, Saxton et al., 1986 and van Genuchten et al., 1991).

Then, soil sustainability (SS) was categorized based on the five classes in Table 3 as follows:

\section{Statistical and geostatistical analysis}

Descriptive statistical analyses were performed in SPSS software package. While geostatistical analyses were applied in ARC/GIS 10.2.2 software to interpolate the data forproviding an estimate of sampled and unsampled location in the study area and producing all maps (i.e., ESA (based on 47locations,SQ, and SS (based on 20 samples).

\section{$\underline{\text { Result and Discussions }}$}

\section{Environmental sensitivity assessment}

The MEDALUS scheme, that used in this study, is used firstly by (Kosmas et al., 1999) and used frequently afterward for assessing ESA in many areas in the Mediterranean Sea and other areas by many other workers such as (Basso et al., 2000, Gad and Lotfy, 2006, Contador et al., 2009, Symeonakis et al., 2016, Tombolini et al., 2016 and Saleh et al., 2018). Symeonakis et al. (2016) reported that ESA framework is the most frequently applied indicator-based system for evaluating land degradation and desertification (LDD) in the Mediterranean region essentially due to its simplicity in model building and its flexibility in the use of relevant variables as indicators. Creating a system which needs an information difficult in obtaining or costly updated, although if it is scientifically significant, would be very restrictive and impractical in huge, complex, environments or with continuous monitoring systems. Therefore, thisdeveloped system allows the easy adding or removing of information layers, when there is a necessity to study specific aspects or areas with larger details (Ferrara, 2004).

\section{Matching the results}

The matching of the physical environment qualities (soil quality, climate quality, vegetation quality) and the management quality was performed to determine the various types of ESAs. Generally, the quantification of different
ES levels can be performed by evaluating the general influence that certain information layers have on the phenomena under study. Based on the data in (Table 4), four general types of ESAs to desertification can be differentiated depending on the state of land degradation: 1) critical areas: areas already highly degraded due to past misuse, exhibiting a threat to the surrounding environment. For example, severely eroded areas under high runoff conditions and sediment loss. This may cause considerable flooding downstream and reservoir sedimentation; 2) fragile areas: areas in which any change in the adequate balance of natural and human activity is probably giving rise to desertification. For example, the impact of predicted climate change due to greenhouse warming is likely to enhance reduction in the biological potential due to drought causing areas to lose their vegetation cover, subject to greater erosion, and finally shift to the Type A category. A land use change, for example, a changeto cereals cultivation, on sensitive soils might cause immediate increase in runoff and erosion, and perchance pesticide and fertilizer pollution downstream; 3) potential ESAs: areas vulnerable to desertification under significant climate change, if a particular combination of land use is applied or where offsite impacts will cause severe problems elsewhere, for instance pesticide transfer to downslopes or down streams under varying land use or socio-economic conditions. abandoned land also, which is not well managed, would be included; and 4) non-threatened areas to desertification: areas with deep to very deep, well drained, nearly flat,coarse or fine textured soils, under semi-arid or wetter climatie conditions, independently of vegetation are considered as (Kosmas et al., 1999 and Ferrara, 2004).

The data obtained in this study, for assessing ESAs, showed that SQI ranges from 1.23 to 1.67 (low or moderate quality), while CQI ranges from 1.59 to 1.69 (moderate quality). Further, VQI varies from 1.26 to 1.80 (moderate to high quality), whereas MQI varies from 1 to 2 (low quality) (Table 5 and Fig. 4). It is observed also according to the presented data in (Table 5 and Fig. 4) that ESAI ranges from 1.30 to 1.81 , which means that all study area is fragile or critical environmentally sensitive areas. Data in Table 6 demonstrates that approximately $64 \%$ of all sample locations are recorded as $\mathrm{C} 3,30 \%$ as $\mathrm{C} 2,2 \%$ as $\mathrm{C} 1$, while $\mathrm{F} 2$ is approximately $4 \%$ of all sample locations. These aspects bring about a high risk of soil degradation and high sensitivity to desertification. The results 
TABLE 2. Relative weighting factors (RWF) depending on the threshold values of soil quality indicators using the cumulative rating $(\mathrm{CR})$ approach

\begin{tabular}{|c|c|c|c|c|c|c|c|c|c|c|}
\hline Limitation & RWF & $\begin{array}{c}\mathrm{AC} \\
\left(\mathrm{cm}^{3} \mathrm{~cm}^{3}\right)\end{array}$ & $\begin{array}{c}\text { AWHC } \\
\left(\mathrm{cm}^{3} \mathbf{c m}^{3}\right)\end{array}$ & $\begin{array}{c}\text { BD } \\
\left(\mathrm{Mgm}^{-3}\right)\end{array}$ & TX. & RFC & SAR & $\begin{array}{l}\text { SOC } \\
(\mathrm{Mg} \\
\left.\mathrm{ha}^{-1}\right)\end{array}$ & $\begin{array}{c}\text { EC } \\
d S \\
\mathbf{m}^{-1}\end{array}$ & pH \\
\hline None & 1 & $>0.20$ & $>0.30$ & $<1.3$ & Loam & $0.6-0.7$ & $<3$ & $70-130$ & $<3$ & $6-7$ \\
\hline Slight & 2 & $0.18-0.20$ & $0.20-0.30$ & $1.3-1.4$ & $\begin{array}{l}\text { Sil, Si, } \\
\text { SiCL }\end{array}$ & $\begin{array}{c}0.5-0.6 \\
0.7-0.75\end{array}$ & $3-6$ & $45-70$ & $3-5$ & $\begin{array}{l}5.8-6 \\
7-7.4\end{array}$ \\
\hline Moderate & 3 & $0.15-0.18$ & $0.08-0.20$ & $1.4-1.5$ & CL,SL & $\begin{array}{l}0.4-0.5 \\
0.75-0.8\end{array}$ & $\begin{array}{l}6- \\
12\end{array}$ & $14-45$ & $5-7$ & $\begin{array}{c}5.4-5.8 \\
7.4-7.8\end{array}$ \\
\hline Severe & 4 & $0.10-0.15$ & $0.02-0.08$ & $1.5-1.6$ & $\begin{array}{l}\text { Sic, } \\
\text { LS }\end{array}$ & $\begin{array}{c}0.35-0.4 \\
0.8-0.9\end{array}$ & $\begin{array}{c}12- \\
20\end{array}$ & $7.5-14$ & $7-10$ & $\begin{array}{l}5.0-5.4 \\
7.8-8.2\end{array}$ \\
\hline Extreme & 5 & $<0.10$ & $<0.02$ & $>1.6$ & $\mathrm{C}, \mathrm{S}$ & $\begin{array}{c}<0.35 \\
>0.9\end{array}$ & $>20$ & $<7.5$ & $>10$ & $\begin{array}{l}<5.0 \\
>8.2\end{array}$ \\
\hline
\end{tabular}

AC: air capacity; AWHC: available water holding capacity; BD: bulk density; TX: texture; RFC: relative field capacity; SAR: sodium adsorption ratio; SOC: soil organic carbon; EC: electrical conductivity.

Source:(Ghaemi et al., 2014) and adopted from Lal (1994).

TABLE 3. Soil sustainability classification based on cumulative rating (CR) approach according to nine soil indicators

\begin{tabular}{lcc}
\hline Sustainability class & RWF & CR of all soil properties \\
\hline High sustainable & 1 & less than 16 \\
Sustainable & 2 & 16 to 21 \\
Sustainable with high input & 3 & 21 to 26 \\
Sustainable with another land use & 4 & 26 to 31 \\
Unsustainable & 5 & more than31 \\
\hline
\end{tabular}

Source: Ghaemi et al., 2014

TABLE 4. ESA Types and corresponding ranges of indices

\begin{tabular}{|c|c|c|c|}
\hline Sensitivity degree & Type & Subtype & ESAI Range \\
\hline \multirow[t]{3}{*}{$\mathbf{H}$} & Critical (Cr) & $\mathrm{Cr} 3$ & higher than 1.53 \\
\hline & & $\mathrm{Cr} 2$ & 1.42 to 1.53 \\
\hline & & $\mathrm{C} 1$ & 1.38 to 1.41 \\
\hline \multirow[t]{3}{*}{$\mathbf{M}$} & Fragile (Fr) & Fr3 & 1.33 to 1.37 \\
\hline & & Fr2 & 1.27 to 1.32 \\
\hline & & Fr1 & 1.23 to 1.26 \\
\hline $\mathbf{L}$ & Potential (P) & $\mathrm{P}$ & 1.17 to 1.22 \\
\hline VL & Non-affected (Nf) & $\mathrm{Nf}$ & Less than 1.17 \\
\hline
\end{tabular}

L: low; M: moderate; H: high; VL: very low

Source:Kosmas et al., 1999 and Canora et al., 2015. 
analysis refers to anobvioussituation of sensitivity to desertification of Kafr Elshiekh governorate. Environmental sensitivity or vulnerability concerns are essential in natural resource management, mainly in the analysis of society and ecosystems interactions (Campo, 2017). As well, avoidance or mitigation the land degradation is a critical issue for the sustainable management in dryland regions (Salvati et al., 2014). This study classified the Kafr-Elsheikh governorate in terms of its ES to desertification. However, there was a previous attempt (Gad and Lotfy, 2006), to evaluate ES, but it was on overall Egypt. Therefore, this study is a deeper analysis for ESAs identification to better understanding of how certain factors contribute to LDD, the utilize of the classification depending on the ESA approach allows us to identify the greatest critical areas, as an integration of driving forces, which are substantial for addressing desertification (Izzo et al., 2013). Because the study area is in North of the Nile Delta in Egypt, and this area is one of the most fertile areas in Egypt, as well this area is subjected to many environmental threatens, therefore, assessing the vulnerability to desertification is very important and essential to avoid many threatens during the planning and decision making in this area. This also because desertification is one of the most major threats to semiarid, arid, and sub-humid environments (Becerril-Piña et al., 2016).

Figure 4 shows also that the east and west of the study area is fragile not critical areas based on the previous mentioned classification of ESAI. This means that although, the most of coastal area in this study is degraded, it contains the least sensitive areas in this study. This may be attributed to its nature because most of this area is virgin didn't subject to many human activities. However, the reclamation activitiesare performed in the coastal area to restore this area due to the increased demand on food because of grown population rate. As well, most of agricultural activities in the coastal arearepresents in horticultures and palms not agricultural crops because of the soil properties (sandy and saline soils) and the climate conditions).The restoration activities and reclamationin this area had led to increasing soil organic matter, soil $\mathrm{C}$ and soil $\mathrm{N}$, in addition to enhancing soil properties according to (Elbasiouny et al., 2017). In addition, the agricultural intensification in the coastal area is not high as in the south part of the study area. All of these reasons may interpret why the coastal area are less sensitivity than the rest of the study area. Canora et al. (2015) explained that the high sensitivity depends mainly on the soil physical characteristics and insufficient maintenance or abandonment of huge agricultural areas which accelerate erosion processes. This may explain the higher sensitivity in the south of the study area than other areas. They explained also that the sensitivity to desertification is less in some zones (such as hills) than other zones because of land use, lack of human-induced alterations to natural settings, and the implementation of good management practices for land protection. As well, they added that human actions represent the most important role in the desertification process.Symeonakis et al. (2016) emphasized that in the Mediterranean area, desertification as a consequence of climatic and human driving forces operating in tandem is not a recent phenomenon. As well, on the Mediterranean coast, the tourism is affecting the natural space of highly valuable environments. Thus, such sensitive areas are subjected to a changed catalog of human induced actions such as urbanization of natural soil, modification the balances of the dune by the construction of ports infrastructure, alteration of marine ecosystems by recreational activities, ...etc, (García-Ayllón, 2018). Therefore, the nature of the coastal area in addition to human activities are the major reason for degradation in this area. Facing the environmental risks of the rising scarcity of natural resources, the advance and protection of preserved resources has been given higher attention (Shi et al., 2018). Furthermore, because the interaction between climate stresses and anthropogenic changes has led the environmental system towards almost irreversible land modifications (Canora et al., 2015), thus expected impacted of the climate change on the study area may maximize the vulnerability to environmental degradation and the sensitivity to desertification. Therefore, the attention should be paid to this area of the North Nile Delta, to minimize the negative effects based on the previous mentioned explanation. In addition, as Canora et al. (2015) illustrated, today, land degradation is extensive and severe. As well,few areas in ours only seem to have adopted good field management practices that successfully sustain land productivity.Evidently, theunderstanding of the problems associated with the desertification process requires not only the detection that the phenomenon exists, but also an inclusive analysis of land with respect to the development of environmental policies.

Egypt. J. Soil. Sci. 58, No. 4 (2018) 
TABLE 5. Descriptive statistics of the partial quality indicators (SQI, CQI, VQI, MQI) and the composite index (ESAI) based on the samples in the studied area

\begin{tabular}{|c|c|c|c|c|c|}
\hline & SQI & CQI & VQi & MQi & ESAI \\
\hline Mean & 1.41 & 1.64 & 1.68 & 1.71 & 1.57 \\
\hline Min. & 1.23 & 1.59 & 1.26 & 1.00 & 1.30 \\
\hline Max. & 1.67 & 1.69 & 1.80 & 2.00 & 0.12 \\
\hline SD & 0.11 & 0.05 & 0.17 & 0.34 & 7.56 \\
\hline CV & 7.67 & 2.83 & 9.92 & 20.10 & fragile tocritical \\
\hline Range & $\begin{array}{c}\text { low to moderate } \\
\text { quality }\end{array}$ & \begin{tabular}{c} 
quality \\
\hline
\end{tabular}
\end{tabular}

TABLE 6. The percentages of observed ESA categories based on samples numbers in this study

\begin{tabular}{ccc}
\hline ESA category & Sample numbers & \% of total samples (47) \\
\hline $\mathrm{Cr} 3$ & 30 & 63.83 \\
$\mathrm{Cr} 2$ & 14 & 29.79 \\
$\mathrm{Cr} 1$ & 1 & 2.13 \\
$\mathrm{Fr} 2$ & 2 & 4.26 \\
\hline
\end{tabular}

Cr: critical; Fr: Fragile

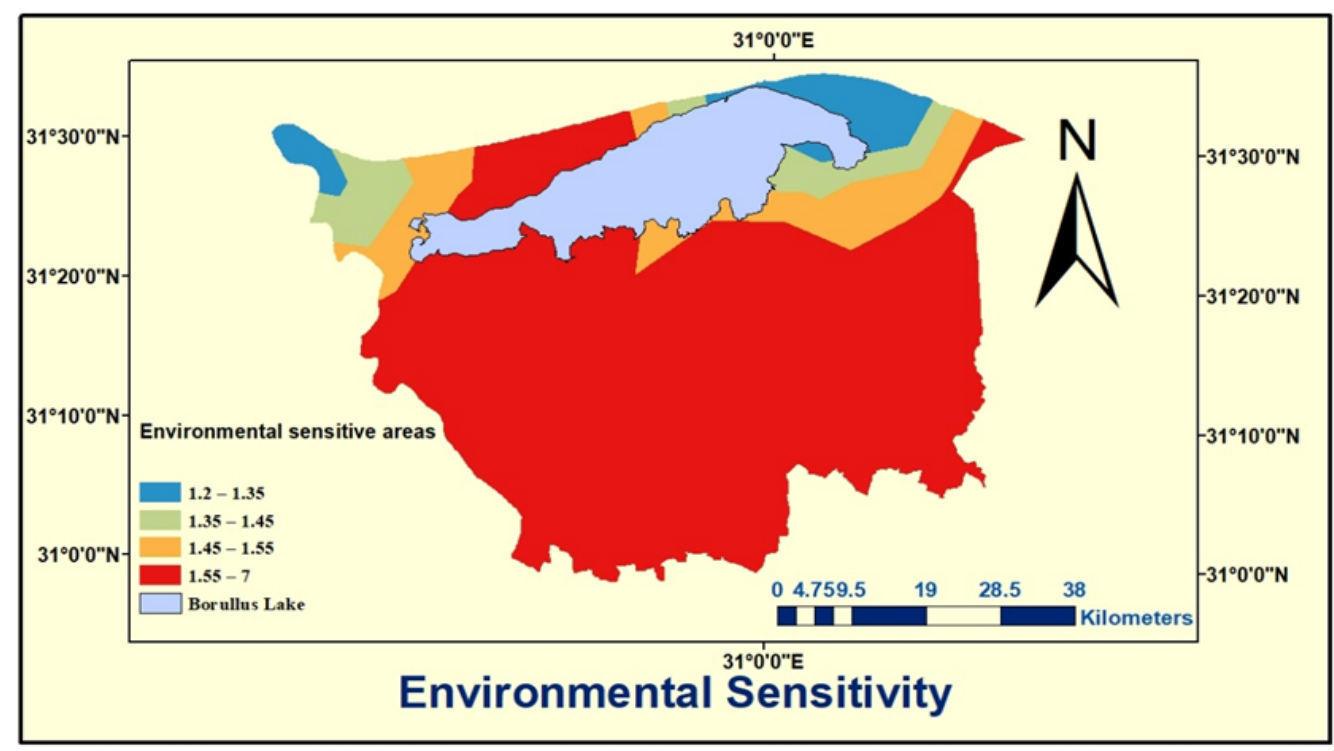

Fig. 4. Assessing the ESAs in Kafr Elshiekh governorate, North Nile delta, Egypt 
Assessing soil quality (SQ)

Based on the descriptive statistical analysis of soil properties included in assigning SQ (Table 7), all considered soil properties was highly variable (based on $\mathrm{CV}$ values) except $\mathrm{pH}$ and $\mathrm{BD}$. According to the above-mentioned weighting method of Ghaemi et al. (2014), the minimum recorded SQ in the studied samples was 26 and the maximum one was 40 . This means that SQ in all studied samples were low or moderate because most thresholds of the studied samples recorded moderate, sever or extreme values.

Depending on the considered factors, SQ is moderate only in small parts in the east and south in the study area, although its high environmental sensitivity. However, the other parts in the study have low SQ (Fig. 5). The least quality parts are located in the north and in the west of the study area which was more environmentally sensitive. There are many reasons for that representing in: 1) this area (which cultured by red culture in Fig. 5) is barren, very degraded, has $\mathrm{pH}$ higher than 8 , has low $\mathrm{C}$ and $\mathrm{N}$ contents and high bulk density (Elbasiouny et al., 2014); 2) this area is high salt-affected as well it is facing constant inundation and salt intrusion due to exposure to these a which likely will lead to elevating water table levels and salt intrusion also to the south of the study area (Khanom, 2016);3) traditional cropping systems, such as crop rotation, mixed cropping, and inter-cropping are replaced by conventional farming. This has resulted in the increased practicing of mono-cropping and anincreasingdependence on irrigation, inorganic fertilizers, and pesticides. Thus, mono-cropping accompanied by the inappropriate applications of inorganic fertilizers, pesticides, and intensified land use without using of organic fertilizers has led to deterioration in soil quality and fertility (Khanom, 2016); and 4) increasing industrial and tourism activities in this area which lead to increase pollution sources and human pressures on the land in this area. On the other hand, moderate SQ in the observed south part in the study area is because of the vulnerability to degradation in this area, therefore, farmers are paying their attention to their agricultural lands in terms of improving the drainage, enhancing the soil nutrients either by organic or synthetic fertilizers, and performing other agricultural processes that minimize the physical degradation in their soil. Furthermore, it is observed from Fig. 5 that the eastern part of the studied area is moderate in soil quality, which should pay the attention to change the management practices and enhancing soil properties in this areato enhance its soil quality, which result not only in higher productivity and enhancing sustainability, but also mitigating the expected impacted of climate change (Elbasiouny et al., 2017). Jónsson et al. (2016) counted the soil threats that may decline soil quality as: erosion, decline in organic matter,soil contamination,soil sealing, soil compaction, decline in soil biodiversity, salinization in addition to floods and landslides. Most of these threats ae found in the study area, theseare enough reasons for declining SQ in the study area in addition to the previous mentioned reasons. Salinization in the study area is main degradation process in this area that affected productivity, soil quality and sustainability. Soil salinity is ascribedto natural factors such as climate, natural drainage models,topographic characteristics, geological structure, space to the sea and indistinctive exploitationof soil and groundwater resources. These natural factors are connected to agricultural management practices. Salinity increases in in surface soil layers, especially close tothe dune belt. Salinity in the surface soils is correlated to unsuitable irrigation practices. This salinity strongly affects plants and lowers the choice of crops due to itis representing the major abiotic stress to plants, in addition to contributing to land degradation (Canora et al., 2015).

TABLE 7. Descriptive statistics for soil properties that included in calculation of SQ and SS

\begin{tabular}{lccccc}
\hline \multicolumn{1}{c}{ Soil property } & Mean & Min. & Max. & SD & CV \\
\hline $\mathrm{pH}$ & 8.63 & 8.18 & 9.01 & 0.30 & 3.44 \\
$\mathrm{EC}$ & 12.98 & 1.60 & 66.95 & 21.47 & 165.40 \\
OCP & 27.05 & 1.52 & 51.56 & 17.61 & 65.06 \\
SAR & 8.15 & 2.65 & 43.29 & 9.95 & 122.09 \\
RFC & 0.64 & 0.30 & 0.94 & 0.22 & 35.21 \\
BD & 1.54 & 1.46 & 1.64 & 0.06 & 3.92 \\
AWHC & 0.01 & 0.004 & 0.02 & 0.01 & 50.81 \\
Air capacity & 0.09 & -0.30 & 0.24 & 0.14 & 156.27
\end{tabular}

Texture The texture of all location was sandy, loam, clay, silty loam, silty clay loam or silty clay

Min; Minimum value; Max.: Maximum value; SD: Standard Deviation; CV: coefficient of variation.

Egypt. J. Soil. Sci. 58, No. 4 (2018) 


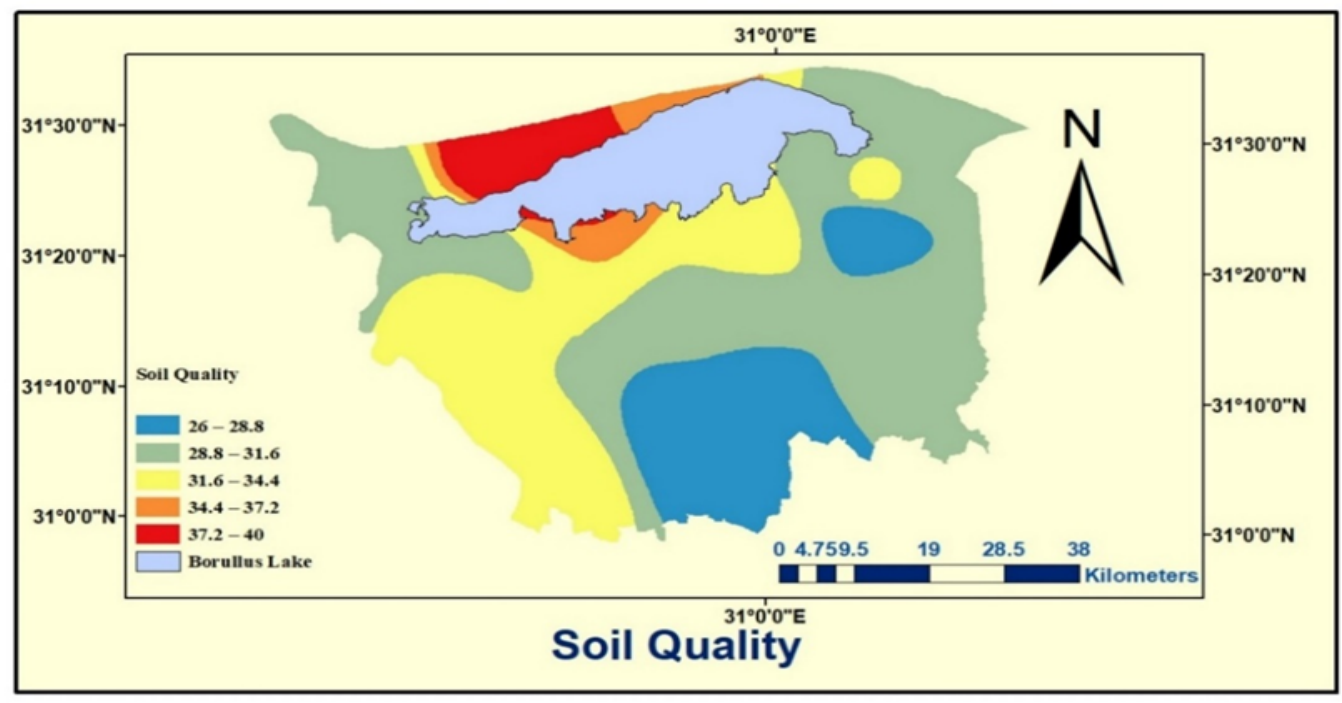

Fig. 5. Soil quality assessmentin Kafr Elshiekh governorate, North Nile delta, Egypt

Soil sustainability (SS)

Currently, the development, ecological restoration and management, andsustainable utilizing of ecological resourceshavebecome key issues for academics (Shi et al., 2018). Identifying sustainable and unsustainable areasplays an essentialrole in the resource management, especiallyin fragile regions (suchour study area). For helping decision makers formulate efficientmanagement strategies, conductinga comprehensive environmental evaluation is imperative. This type of evaluation enables the identification of areas atrisk of losing functions that will threaten future efforts related tosustainable land management (Zou and Yoshino, 2017).Soil quality indices arereported as the most appropriated methodsfor evaluating soil sustainability because of easeof use, flexibility and quantification (Ghaemi et al., 2014). As the environmental monitoring is concerning the current status of key parametersand objects of interest (Nilssen et al., 2015), it is shown from Fig. 6, most of the soil in the studied area is unsustainable (approximately $60 \%$ of the studied area) except the same southern part (i.e., that was higherin SQ), it is sustainable with high inputs (approximately $10 \%$ of the studied area) or with another land use (approximately 30\% of the studied area).This means that using soil for agricultural cropping purposes in this area should be changed to another land use or management practices should be improved to maintain the soil and resources there. The unsustainability of this area is attributed to many reasons such as:

\section{Soil properties}

$\mathrm{pH}$ is higher than $8, \mathrm{EC}$ varied widely in this partbetween very low to more the $4 \mathrm{dS} \mathrm{m}^{-1}$, high bulk density (which indicates increasing compaction), heavy texture and low organic matter; (Elbasiouny et al., 2014) and unsustainable agricultural practices.Morugán-Coronado et al. (2015) reported that within agricultural lands, the Mediterranean Belt is characterized by the depletion of soil organic matte after millennia of ploughing and burning. In the $20^{\text {th }}$ century, the appearanceof herbicides, chemical fertilizers, and biocides drasticallyaltered the function and the structure of microbial communities, changing the terrestrialecosystems, which has significant implications for soil quality. They also added that soil quality is the "foundation" of the sustainable developmentof terrestrial ecosystems. This explanation affirmed the relationship between SQ and SS assessment. It's observed from the descriptive investigation of the western part of the studied area that there are many reasons for unsustainabilityin addition to the previous degradation reasons. Among these reasons, in small coal mining industries, is urban sprawling as shown in Fig. 7.

\section{Conclusion}

Utilizing MEDALUS scheme in this study has led to observe that the degraded and salt-affected areas in the north part and some parts in the south in the study area is critically environmental sensitive to desertification, whereas, the other parts of the study area are fragile. Using soil properties as 


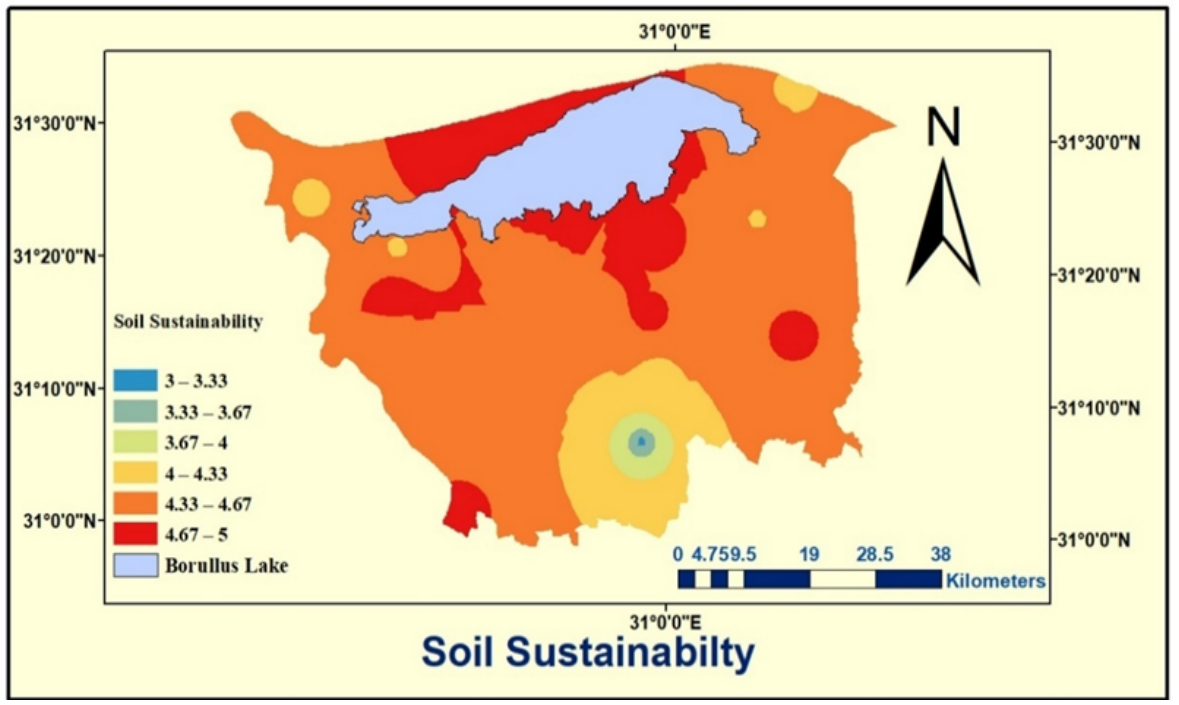

Fig. 6. Soil sustainability assessmentin Kafr Elshiekh governorate, North Nile delta, Egypt

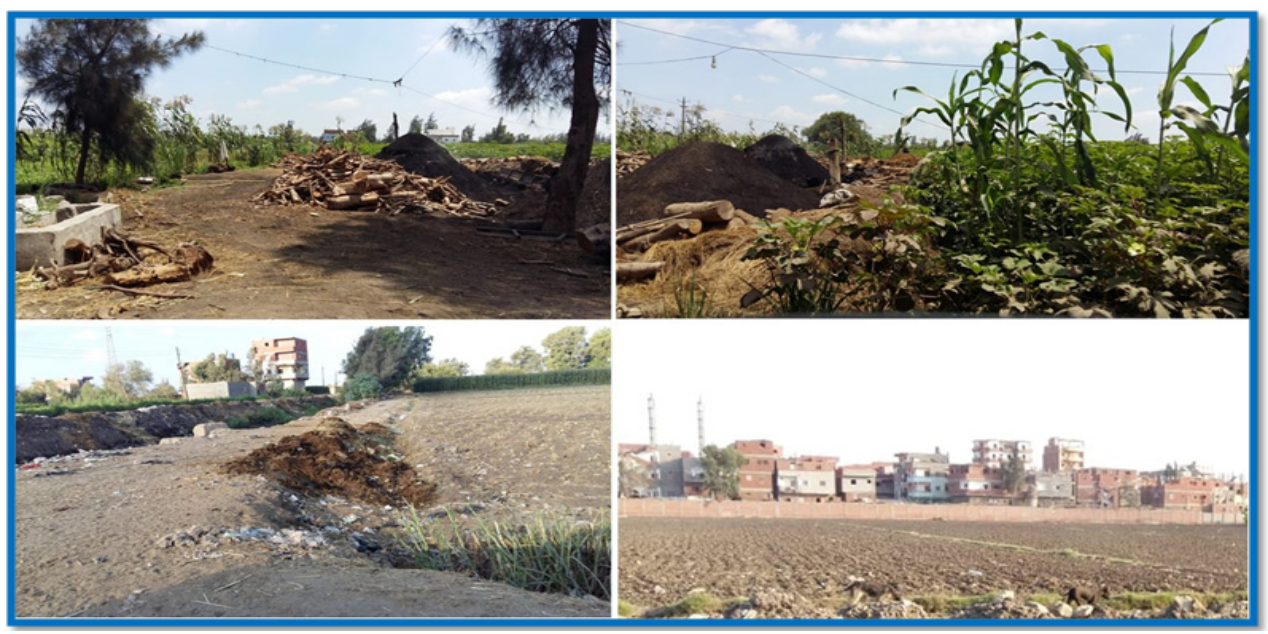

Fig. 7. Some deterioration photos (taken by the author) in the study area

indicators to assess the quality and sustainability of soil showed that most of the study area has low or moderate soil quality, as well is classified as unstainable soils. This is indicator for that the study area is required for good management practices. This isnot only to avoid the decline in the agriculture productive because of vulnerability to desertification, but also to enhance the soil quality to reach to the sustainability in this vital area in Egypt. Evaluation and monitoring studies are very important in decision making and management planning especially in vulnerable areas to degradation and environmental changes. Therefore, the assessment of environmental sensitivity, soil quality and sustainability should be included in the future strategic planning in this area to maximize the benefits and lower the impacts of degradation and global changes in the environment.

\section{References}

Adams,W.A. (1973) The effect of organic matter on the bulk and true densities of some uncultivated podzolic soils, J. Soil Sci., 24 (1), 10-17

Ali, R.R., El Baroudy, A.A. (2008) Use of GIS in mapping the environmental sensitivity to desertification in Wadi El Natrun depression, Egypt. Aust. J. Basic Appl. Sci. 2 (1), 157-164.

Basso, F.,Bove, E.,Dumontet, S., Ferrara, A., Pisante, M.,Quaranta, G., Taberner, M. (2000) Evaluating environmental sensitivity at the basin scale through 
the use of geographic informationsystems and remotely sensed data: an examplecovering the Agri basin (Southern Italy). CATENA, 40, 19-35.

Campo, A.G.D. (2017) Mapping environmental sensitivity: A systematic online approach to support environmental assessment and planning. Environmental Impact Assessment Review 66, 8698. http:// dx.doi.org/10.1016/j.eiar.2017.06.010.

Canora, F., D’Angella, A., Aiello., A. (2015)Quantitative assessment of the sensitivity to desertification in the BradanoRiver basin (Basilicata, southern Italy). Journal of Maps, 11(5), 745-759, http://dx.doi.org/ 10.1080/17445647.2014.980857.

Contador, J.F.L, Schnabel, S.., Gutie'Rrez, A.G., Ferna' Ndez, M.P. (2009) Mapping sensitivity to land degradation in Extremadura.Sw Spain. Land Degrad. Develop. 20, 129-144.

Doran JW, Parkin TP. (1994) Defining and assessing soil quality. In: Doran JW, Coleman DC, Bezdicek DF, Stewart BA (Ed.), Defining Soil Quality for a Sustainable Environment, Madison, WI. Soil Sci. Soc. Am., 35, 3-21(special publication).

El- Baroudy, A.A. (2013) Evaluating Environmental Sensitivity to Desertificationin El-Fayoum Depression, Egypt. Egypt. J. Soil Sci., 53 (3), 445-460.

Elbasiouny, H., Abowaly, M., Abu_Alkheir, A., Gad, A. (2014) Spatial variation of soil carbon and nitrogen pools by using ordinary Kriging method in an area of north Nile Delta, Egypt. CATENA, 01(113),70-78.

Elbasiouny, H., Abowaly, M., Abu Alkheir, A., Gad, A., Elbehiry, F. (2017) Restoration and sequestration of carbon and nitrogen in degraded northern coastal area in Nile Delta, Egypt for climate change mitigation. Journal of Coastal Conservation, 21,105-114, DOI 10.1007/s11852-016-0475-3.

Elbasiouny, H., Elbehiry, F., Abowaly, M. (2017a) Soil quality- special focus on salt-affected soils: review and case study in Egypt. Environment, Biodiversity and Soil Security, 85-100.

Elbehiry, F., Elbasiouny, H., El-Henawy, A. (2017) Boron: Spatial Distribution in an Area of North Nile Delta, Egypt, Communications in Soil Science and Plant Analysis, 48, 3, 294-306, DOI: 10.1080/00103624.2016.1269795.

Elbehiry F., Mahmoud M.A., Negm A. (2018) Land Use in Egypt's Coastal Lakes: Opportunities and Challenges. In: The Handbook of Environmental Chemistry. Springer, Berlin, Heidelberg.DOI https://doi.org/10.1007/698_2018_250.

El-Nesr, M. N. (2006) Subsurface drip irrigation system development and modeling of wettingpattern distribution.Presented to the Graduate School,
Faculty of Agriculture, Alexandria University, Egypt.In Partial Fulfillment of the Requirements for the Degree of Doctor of PHILOSOPHY in Agricultural Engineering.

Ferrara, A. (2004) Expert system for evaluating the Environmental Sensitivity Index (ESI) of a local area: methodology. DIS4ME Homepage |C DESERTLINKS 2004.https://esdac.jrc.ec.europa. eu/public_path/shared_folder/projects/DIS4ME/ esi_jan_05/method.htm. Accessed July 2018.

Gad, A., Lotfy, I. (2006) Use of remote sensing and GIS in mapping the environmental sensitivity areas for desertification of Egyptian territory. In: Proceedings of the Second International Conference on Water Resources and Arid Environment 2006, Riyadh, Kingdom of Saudi Arabia, 26-29 November 2006.

García-Ayllón, S. (2018) GIS Assessment of Mass Tourism Anthropization in Sensitive Coastal Environments: Application to a Case Study in the Mar Menor Area. Sustainability, 10, 1344; doi:10.3390/su10051344.

Ghaemi, M., Astaraei, A.R., Emami, H., Mahalati, M.N., Sanaeinejad, S.H. (2014) Determining soil indicators for soil sustainability assessment using principal component analysis of Astan Quds- east of Mashhad- Iran. Journal of Soil Science and Plant Nutrition, 14 (4), 987-1004.

IPCC, 2014. Climate change 2014 impacts, adaptation, and vulnerability.Summaries, frequently asked questions and cross chapter boxes. In: A Working Group II Contribution to the Fifth Assessment Report of the Intergovernmental Panel on Climate Change, Geneva, Switzerland (p. 190).

Izzo, M., Araujo, N., Aucelli, P. P. C., Maratea, A., Sánchez, A. (2013) Land sensitivity to desertification in the Dominican Republic: an adaptation of the ESA methodology. Land Degrad. Develop. 24, 486-498

Jónsson, J.Ö.G., Davíðsdóttir, B., Jónsdóttir, E.M, Kristinsdóttir, S.M., Ragnarsdóttir, K.V., (2016) Soil indicators for sustainable development: A transdisciplinary approach for indicator development using expert stakeholders. Agriculture, Ecosystems and Environment 232: 179-189 http:// dx.doi.org/10.1016/j.agee.2016.08.009.

Karlen D.L., Mausbach, J.J., Doran, J.W., Cline, R.G., Harris, R.F., Schuman, G.E. (1997) Soil Quality: A Concept, Definition, and Framework for Evaluation. Soil Sci. Soc. Am. J., 61, 4-10.

Keller, J., Karmeli, D.(1975) Trickle irrigation design, Rain Bird Sprink. Manif.Corp.133 pp.

Khanom, T. (2016) Effect of salinity on food security in the context of interior coast of Bangladesh. Ocean

Egypt. J. Soil. Sci. 58, No. 4 (2018) 
\& Coastal Management 130: 205-212. http://dx.doi. org/10.1016/j.ocecoaman. 2016.06.013

Kosmas, C., Kirkby, M., \&Geeson, N. (Ed.) (1999) The MEDALUS project Mediterranean desertificationand land-use. Manual on key indicators of desertification and mapping environmentally sensitive areasto desertification. Luxembourg: Office for Official Publications of the European Communities.

Lal, R. (1994) Methods and guidelines for assessing sustainable use of soil and water resources in the tropics.Soil Management Support System, USDANRCS, Washington, DC. pp:1-88.

Morugán-Coronado, A., García-Orenes, F., Cerdà, A. (2015) Effect of land management on soil properties in flood irrigated citrus orchards in Eastern Spain. SOIL Discuss.,2, 1-27. www.soildiscuss.net/2/1/2015/. doi:10.5194/soild-2-1-2015.

Nelson, D. W., and L. E. Sommers. 1996. Total carbon, organic carbon and organic matter. In Methods of soil analysis: Part 3, Ed.: J. M. Bigham, 961-1010. SSSA, Madison, USA: Chemical Methods.

Nilssen, I., Ødegård, Ø, Sørensen, A.J., Johnsen, G., Moline, M.A., Berge, J. (2015) Integrated environmental mapping and monitoring, a methodological approach to optimise knowledge gathering and sampling strategy. Marine Pollution Bulletin, 96 (2015) 374-383. http://dx.doi. org/10.1016/j.marpolbul.2015.04.045.

Page, A.L., Miller, R.H., Baker, D.E. (1982) Methods of Soil Analysis - Part 2 - Chemical and Microbiological Properties, $2^{\text {nd }}$ ed.

Saleh, A. M., Belal, A. B., Jalhoum, M. E. (2018) Quantitative Assessment of Environmental Sensitivity to Desertification in Sidi Abdel-Rahman Area, Northern West Coast.of Egypt. Egypt. J. Soil Sci. 58 (1), 13 -26.

Salvati, R., Salvati, L., Corona, P., Barbati, A., Ferrara, A. (2014) Estimating the sensitivity to desertification of Italian forests.iForest 8: 287-294 URL:http:// www.sisef.it/iforest/contents/?id=ifor1111-008. doi: 10.3832/ifor1111-008.

,Seker, C.,Özaytekin, H.H., Negi s, H.,Gümü s, I., Dedeŏglu, M.,Atmaca, E., Karaca, Ü. (2017) Identification of regional soil quality factors and indicators: a case study on an alluvial plain (central Turkey). Solid Earth, 8, 583-595. www.solid-earth. net/8/583/2017/. doi:10.5194/se-8-583-2017.

Shi, Y. Lib, J., Xie, M. (2018) Evaluation of the ecological sensitivity and security of tidal flats in Shanghai. Ecological Indicators 85: 729-741. https://doi.org/10.1016/j.ecolind. 2017.11.033.
Saxton, K. E., Rawls, W.J., Romberger, J.S.,Papendick, R. I. et al. (1986) Estimating generalized soil-water characteristics from texture. URL:http://www. bsyse.wsu.edu/saxton. Soil Sci. Soc. Amer. J. 50(4), 1031-1036

Symeonakis, E., Karathanasis, N., Koukoulas, S., Panagopoulos, G. (2016) Monitoring sensitivity to land degradation and desertification with the environmentally sensitive area index: the case of Lesvos Island. Land Degrad. Develop. 27, 1562 1573. DOI: $10.1002 / \mathrm{ddr} .2285$.

Tombolini, I., Colantoni, A., Renzi, G., Sateriano, A., Sabbi, A., Morrow, N., Salvati, L. (2016) Lost in convergence, found in vulnerability: A spatiallydynamic modelfor desertification risk assessment in Mediterranean agro-forest districts.Science of the Total Environment.http://dx.doi.org/10.1016/j. scitotenv. 2016.06.049.

United States Salinity Laboratory Staff, (1954) Diagnosis and improvement of saline and alkali soils.Handbook 60.United States Department of Agriculture (USDA), Washington, DC.

vanGenuchten M. Th, (1980) A closed-form equation for predicting the hydraulic conductivity of unsaturated soils. Soil Sci Soc. Am J. 44, 892-898.

Wood, S.L.R., Jones, S,K., Johnson, J.A c, Brauman, K.A., Chaplin-Kramer, R., Fremier, A.,Girvetz, E., Gordon, L.J., Kappel, C.V., Mandle, L., Mulligan, M., O'Farrell, P., Smith, W.K., Willemen, L., Zhang, W., DeClerck, F. A. (2018) Distilling the role of ecosystem services in the Sustainable Development Goals. Ecosystem Services, 29, 70-82.

Xu, L., N. P. He, G. R. Yu, D. Wen, Y. Gao, and H. L. He (2015) Differences in pedotransfer functions of bulk density lead to high uncertainty in soil organic carbon estimation at regional scales: Evidence from Chinese terrestrial ecosystems, J. Geophys. Res. Biogeosci., 120, 1567-1575, doi:10.1002/ 2015JG002929.

Zeydan, B.A. (2005) The Nile Delta in a global vision. Ninth International Water Technology Conference, IWTC9 2005, Sharm El-Sheikh, Egypt, pp. 31-40.

Zou, T., Yoshino, K. (2017) Environmental vulnerability evaluation using aspatial principal components approach in the Daxing'anling region, China. Ecological Indicators, 78 (2017) 405-415. http:// dx.doi.org/10.1016/j.ecolind.2017.03.039. 


\section{تقييم الحساسية البيئية للتصحر، وجودة واستدامة التربة في منطقة في شمال الالتا بمصر \\ هبة البسيونى البهى \\ كلية الاقتصاد المنزلى - جامعة الأزهر}

هناك و عي متز ايد ببعض القضايا البيئية المترابطة مثل التغير و التدهور البيئي و التصدر. لذلك فدراسات التقبيم

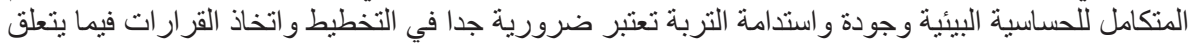

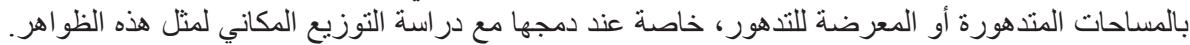

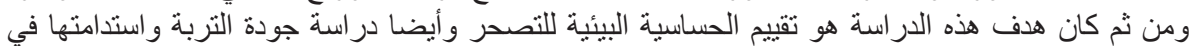

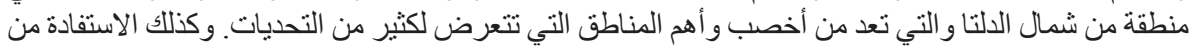

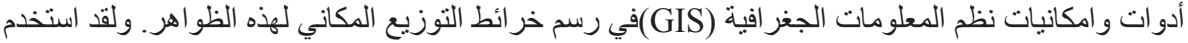

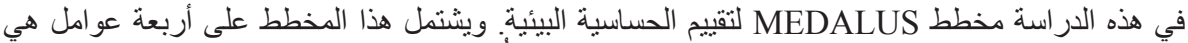

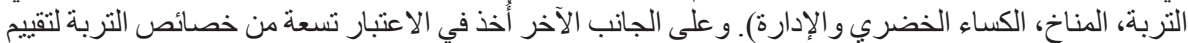

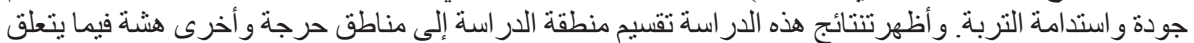

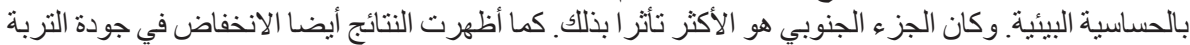

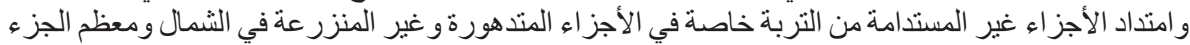

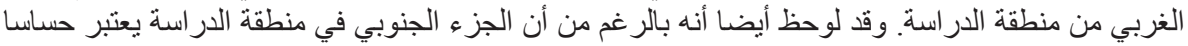

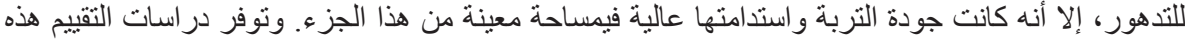

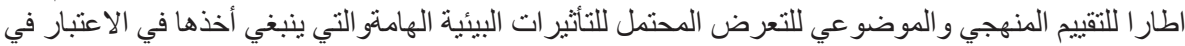
التخطيط الاستر اتيجي في هذه المنطقة. 